“Historical Studies on Mortality," special issue, Canadian Studies in Population 39, no. 3-4 (2012): 139-141.

\title{
Sex and War: How Biology Explains Warfare and Terrorism and Offers a Path to a Safer World
}

\author{
by Malcolm Potts and Thomas Hayden \\ Dallas, TX: BenBella Books, 2008 \\ ISBN 978-1-933771-57-1 \\ Hardcover, \$29.00, 462 pp.
}

Reviewed by Paul Rutherford
University of Toronto
rthfrdpl@netrover.com

Sex and War is symptomatic of a style of argument that has grown up around "biopolitics," a particular approach to governance commonplace in modern times (see Lemke 2011). The object of biopolitics is "the conduct of living and the living," in the words of one scholar (Gordon 1991: 8). According to Michel Foucault, who first defined the term, biopolitical enterprises operate on populations, seeking to control "the biological or biosociological processes characteristic of human masses" (Foucault 2003: 250). Its rise, so he observed, marked the onset of modernity when authorities, both state and non-state, set out to govern large bodies of people at a distance, to co-ordinate and centralize rule, suitable to the needs of the emerging nation-states and eventually the global community. Biopolitics has led the world in two contradictory directions. It took on a lethal cast when wedded to state racism, leading to segregation, eugenics, and eventually, as in the case of Nazi Germany, to genocide in an effort to eliminate "life unworthy of living." That variety has provoked the outcries of a number of critics, notably the Italian philosophers Giorgio Agamben and Roberto Esposito. But, when tied to liberalism, biopolitics has also fostered the growth of public health and social medicine, the welfare state, and the emergence of human rights in the democracies of the twentieth century (see Dickinson 2004). In both cases the style of argument "biologizes" the public sphere by turning all sorts of issues into problems of managing desires and drives, of remaking the very "nature" that supposedly undergirds life. In particular it divides people according to assorted social and demographic characteristics, constituting thereby specific populations, so as to make them governable. Normally it draws its intellectual force from some "discourse of truth" about the real nature of human life (see Rabinow and Rose 2006). Around any population there arise narratives of order and disorder, expressions of crisis, and plans for reform and improvement. The argument of biopolitics, in short, partakes of the rhetorics of dystopia and utopia.

The authors of Sex and War seem eminently suited to the reimaginings of biopolitics. The primary author, the much-accomplished Malcolm Potts, is a physician and a biologist, a pioneer of the international birth control project, author of many books, and presently an academic at the University of California in Berkeley. His voice presidesoften the text is dotted with "I's" - when he recounts the lessons of his experience in the wider world. Potts adheres to what he calls "evolutionary psychology," which finds its mentors in Charles Darwin and E.O. Wilson (though, ironically, there are touches of Sigmund Freud as well in the text). Apparently the book grew out of a collaborative course he taught on the history of warfare, which inspired the desire to discover the biological roots of warfare. The second author, the much younger Thomas Hayden, a onetime biologist, is a freelance journalist and sometime university lecturer who has written on medicine in wartime and specializes in environmental topics. In addition, Potts' wife Martha Campbell, who worked with her husband in some of his international endeavours, contributed to the chapters on women.

They tell a very long story about warfare across the span of primate and especially human existence, a story replete with detail about what chimpanzees do, the behaviours of early bomo sapiens, the lessons of history, and the 
character of modern war and terrorism. Most of this is drawn from a raft of secondary sources (the book boasts 554 endnotes), occasionally spiced with personal reminiscences by Malcolm Potts. The rapid survey of the past is interesting and informative, though occasionally a bit overwhelming, especially because the authors bounce around from ape to human, ancient to modern, men to women, a technique of juxtaposition which may serve to underline their hypothesis about human nature but which can also confuse and disorient a reader. They do, where possible, ground their story in a lot of statistical correlations about the growth and characteristics of populations at different times and in different places. More tiresome is the constant repetition of their argument, especially the supposed persistence of what the authors keep calling "Stone Age behaviours" right up to the present day. They expend most of their energies answering the first question of their subtitle, "How Biology Explains Warfare and Terrorism." They actually spend a lot less time answering the second, "How Biology Offers a Path to a Safer World." But the result is a popular work of exposition which is thoroughly grounded in academic analysis.

The hypothesis is simple — indeed, so simple that Potts and Hayden recognize that they can easily be charged with the sin of reductionism. They fear a future apocalypse fashioned by the persistence of "Stone Age behaviours." The underlying cause of war is the predisposition of young males to form teams that prey on their neighbours in search of land, resources, and women. That predisposition was established in the primate male by the demands of flourishing through the process of evolution back in the recesses of time, a legacy that has cursed human history. Apparently, women are much less likely to engage in what the authors call "team aggression," because their nature dictates a more social_even pacific — response to peril. Likewise, old males are less prone to this predisposition, although they too often accept the division of humanity into ingroups and outgroups (this taken from sociology), where the chief loyalty is owed to one's own community and the enemy is always the Other. It is this predisposition to team aggression which drives war, whether in 10,000 BCE or nowadays. Even though the authors deny any anti-male bias, Sex and War leaves the impression that horny young men are always a dangerous kind of life that threatens the future, another characteristic of biopolitics which at its worst divides life into worthy and unworthy, good and bad.

Biology is not destiny, though. Rather nurture, or culture and experience and environment, has and can moderate the desires and drives of violence. Potts and Hayden do consider the efforts to subject war to assorted rules that might limit its horrors. They rail against the ill effects of propaganda and sensationalism which work to "dehumanize" and "de-individualize" those who belong to outgroups. They cast doubts on the truth of religion, and champion the cause of science and reason, most especially sociobiology which constitutes their "discourse of truth," even if science has given humanity the means to destroy itself. One essential cure is to empower women in the developing world because their influence in the public sphere will calm the drive to warfare. That is linked to the success of campaigns for family planning - in short, population control, which would result in fewer young males, smaller and more affluent families, and a better age balance in the community. The authors presume that liberated women will voluntarily seek to limit their pregnancies to ensure their own health and that of their offspring. It is one of the characteristics of biopolitical thinking (or at least the liberal or affirmative variety) to work with desire and "nature," to presume that one should govern through persuasion rather than through coercion. Likewise, the authors wish to channel team aggression into prosocial activities such as sports or even relief work, this time manipulating male desires to secure a worthwhile goal.

What is missing here, however, is an account of the means by which governors might actually realize any of these laudable pursuits of, say, empowering women or limiting population growth. Which is why Sex and War has more of a utopian than a practical cast. But the real difficulty is with the overall hypothesis of the book. Is the predisposition of team aggression embedded in male genes? Is a predisposition for empathy more emphatic in a woman's genes? Has evolution cursed humanity with contradiction? Their case is not persuasive.

There are two key problems with their argument. First off, the notion that team aggression is, or ever was, a male trait looks doubtful. Yes, aggression and love may indeed be part of human nature, a conclusion that Freud came to back in the 1920s. However, team aggression is not a predisposition but a tactic that a group might employ should the conditions seem appropriate. Likewise the tactic of assassination, commonly the work of a single individual, might meet the needs of a particular situation. But assassination—or its contemporary offshoot, suicide bombing-is hardly a predisposition of males or females. Despite all the talk about what is written in the genes, which sometimes seems as though the authors were believers invoking a god, there is a fundamental confusion between what might well be a drive, like sex, and a tool, namely, team aggression. Sex and War suffers from what in semantics or philosophy is called a category error. 
The other problem grows out of the authors' understanding of modernity. Whatever the findings about the proclivities of certain kinds of chimpanzees, the nature of modern war differs not just in scale but in character. Sex and War largely discounts the import of power, both the structure of authority and the relations of power. To repeat an old cliché, wars are usually generated by old men, the people in authority - it is the young who fight them and the old who direct them. The few contemporary instances where a woman has been in command hardly support a strong case about the pacific influence of female genes; for example, each of the countries ruled by Indira Ghandi, Golda Meir, and Margaret Thatcher engaged in warfare during their watch. We live in a global order of nation-states where war remains an acceptable tool of public policy, even what is called "humanitarian intervention," that serves the biopolitical ends of saving oppressed or threatened populations. The mental universe of citizens and, therefore, their capacity for organized violence is shaped by the impact of religious and secular ideologies, and most especially by a series of nationalisms which divide the world's population into competing collections of friends and enemies. You may find the origins of modern war in the quest for power, the effects of inequality, the influence of false consciousness, or the struggle for resources. The talk of "Stone Age behaviours" serves only to denigrate the leaders, such as President George W. Bush, that many liberals dislike.

Flaws and all, Sex and War remains an entertaining romp through history. But it is neither an explanation of that history nor a blueprint for a better world. Rather, it is an expression of a style of thought about the governance of life (albeit an affirmative biopolitics, not the lethal variety) that, for good or ill, is widespread in Western Europe and North America these days.

\section{References}

Dickinson, E.R. 2004. Biopolitics, fascism, democracy: Some reflections on our discourse about "Modernity." Central European History 37(1/January):1-48.

Foucault, M. 2003. "Society Must Be Defended:” Lectures at the Collège de France 1975-1976. Translated by D. Macey. New York: Picador.

Gordon, C. 1991. Governmental rationality: An introduction, in The Foucault Effect: Studies in Governmentality, edited by G. Burchell, C. Gordon, and P. Miller. Chicago: University of Chicago Press, pp. 1-51.

Lemke, T. 2011. Biopolitics: An Advanced Introduction. Translated by E.F. Trump. New York \& London: New York University Press.

Rabinow, P., and N. Rose. 2006. Biopower today. BioSocieties 1:195-217. 